\title{
PENYUSUNAN BUKU "BERCERITA UNTUK BINA DAMAI: KUMPULAN CERITA RAKYAT DARI BERBAGAI PENJURU DUNIA"
}

\author{
Elyzabeth B. Nasution ${ }^{1}$, Edwin M.B. Tambunan ${ }^{2}$ \\ ${ }^{1}$ Program Studi Hubungan Internasional, Universitas Pelita Harapan (UPH) \\ ${ }^{2}$ Program Studi Hubungan Internasional, Universitas Pelita Harapan (UPH) \\ elyzabeth.nasution@uph.edu, edwin.tambunan@uph.edu
}

\begin{abstract}
Abstrak
Bercerita atau storytelling dipercaya sebagai sebuah instrumen efektif dalam mewariskan pengetahuan, nilai, dan karakter. Tidak hanya di Indonesia, metode bercerita juga dilakukan oleh beragam suku bangsa di seluruh penjuru bumi. Melalui cerita, proses konstruksi sebuah nilai atau karakter berjalan dengan menyenangkan karena bercerita merupakan kegiatan yang menghibur. Dengan cerita, siapapun dapat belajar tanpa merasa digurui. Para pegiat perdamaian juga sudah membuktikan kekuatan cerita dan bercerita untuk memelihara ingatan, membantu pemulihan, dan membina perdamaian. Menyadari hal ini, tim Youth \& Peace Project di bawah Program Studi Hubungan Internasional mencetuskan ide penyusunan buku bertajuk "Bercerita untuk Bina Damai: Kumpulan Cerita Rakyat dari Berbagai Penjuru Dunia." Proses penyusunananya merupakan berkah positif dari pandemi Covid-19. Para mahasiswa yang seharusnya menjalankan kerja praktik di lapangan, akhirnya harus mengambil satu mata kuliah sebagai pengganti kerja praktik. Ide penyusunan buku kemudian diintegrasikan ke dalam mata kuliah Resolusi Konflik. Para mahasiswa diminta menuliskan kembali sebuah cerita yang mengandung unsur perdamaian. Setelah melalui rangkaian proses penyaringan dan penyempurnaan, buku ini terbit dengan tujuan utama menjadi materi bina damai yang dapat dibacakan kapan saja, kepada siapa saja, atau menjadi bagian pembuka (ice breaking), kegiatan utama, atau penutup dari lokakarya atau pelatihan dalam rangka PkM.
\end{abstract}

Kata Kunci: Bercerita (Storytelling), Cerita Rakyat, Bina Damai, Pendidikan Perdamaian

\section{PENDAHULUAN}

Bercerita, atau dalam bahasa Inggris storytelling, adalah tindakan menyampaikan atau menuturkan suatu kisah melalui narasi lisan (Senehi, 2000). Kegiatan bercerita bukanlah sesuatu yang asing untuk masyarakat Indonesia. Pada berbagai suku bangsa di nusantara, yang kebanyakan mewariskan kebudayaannya dari generasi ke generasi menggunakan tradisi lisan; bercerita adalah bagian yang melekat dalam masyarakat. Pewarisan nilai-nilai dan karakter mulia kepada generasi baru pada fase kanak-kanak biasanya dilakukan melalui berbagai kesempatan bercerita, baik itu bercerita tentang pengalaman faktual maupun bercerita tentang hal-hal yang sifatnya legenda, mitos, fabel, epos, dan dongeng. Kegairahan bercerita inilah yang menyebabkan kita dapat dengan mudah menemukan cerita-cerita rakyat (folktales) di berbagai suku bangsa di tanah air.

Tumbuh suburnya cerita rakyat di nusantara mengindikasikan bahwa masyarakat di beragam 
suku bangsa menyakini kekuatan cerita untuk melakukan perubahan sekaligus untuk melestarikan nilai-nilai dan karakter. Melalui cerita, para pendengar dapat diajak untuk mengubah perilaku dan hidupnya apabila tidak ingin berakhir buruk seperti tokoh antagonis dalam cerita yang disampaikan. Dengan cerita, para pendengar juga diajak untuk menyakini bahwa melakukan hal-hal benar seperti yang diperlihatkan para tokoh protagonis akan membuat masyarakat hidup lebih baik, aman, dan tenteram.

Berbagai suku bangsa di tanah air ternyata tidak sendirian dalam melihat kekuatan cerita. Tradisi bercerita menggunakan cerita rakyat ditemukan di hampir semua suku bangsa di muka bumi ini. Kenyataan ini, berikut keampuhan cerita dalam memikat serta mengubah pendengar, telah menarik perhatian para pakar resolusi konflik dan perdamaian. Bercerita kemudian dikembangkan sebagai salah satu metode dalam bina damai, baik semasa konflik berlangsung maupun setelah perdamaian dicapai.

Bagi para pegiat perdamaian dan resolusi konflik, bercerita bermanfaat untuk tiga hal berikut ini: 1) memory (ingatan); 2) recovery (pemulihan); 3) character building (bina karakter). Cerita dan bercerita dapat membantu proses pendokumentasian berbagai kejadian saat konflik atau perang berlangsung. Dokumentasi ini sangat penting untuk mempertahankan ingatan akan konflik dan perang yang terjadi. Hasil dokumentasi dapat berguna untuk tiga hal. Pertama, dokumentasi atas cerita dari pelaku, penyintas, maupun pihak lainnya, dan publikasi yang dilakukan atas cerita mereka dapat menggugah kesadaran kolektif maupun para pihak yang bertikai untuk menghentikan konflik dan perang. Kedua, dokumentasi atas cerita dapat membangun dan memelihara ingatan kolektif sehingga akan membuat siapapun tidak akan pernah tergerak lagi untuk kembali kepada kepahitan hidup di masa konflik dan perang. Ketiga, cerita yang didokumentasikan dengan baik akan membantu komisi kebenaran bekerja pascakonflik karena akan menjadi sumber informasi penting untuk mengidentifikasi pelaku dan penyintas sehingga penegakan keadilan lebih mudah dilakukan demi terciptanya rekonsiliasi. Dokumentasi cerita para tentara anak di Liberia yang dilakukan oleh Agnes
Fallah Kamara-Umunna, seorang penyiar radio PBB di Liberia sewaktu konflik berlangsung, dan Emily Holland, seorang produser CNN kala itu, merupakan contoh yang baik untuk menunjukkan tiga kegunaan cerita dan bercerita dalam membangun ingatan public (Kamara-Umunna \& Holland, 2011).

Bercerita juga menjadi kegiatan yang sangat membantu dalam pemulihan para penyintas konflik dan peperangan. Melalui bercerita para penyintas dapat mengekspresikan pengalaman traumatis yang mereka alami. Bercerita memberi kesempatan kepada mereka menumpahkan luka batin yang dialami sehingga tidak perlu menyimpan dan membawanya sebagai beban hidup sepanjang hayat. Bercerita memungkinkan mereka untuk mengalami katarsis atau kelegaan emosional setelah mengalami ketegangan dan pertikaian batin akibat suatu lakuan dramatis. Bercerita membantu penyembuhan penyintas dan membantu siapapun yang mendengarkan mereka untuk memahami situasi sehingga dapat kemudian menentukan tindakan lebih lanjut. Dalam konteks pemulihan secara komprehensif, Benjamin Maiangwa dan Sean Byrne (2015, Hal. 85-110) menemukan setidaknya ada lima manfaat dari kegiatan bercerita, yaitu: 1) menjadi tempat yang aman baik bagi pelaku maupun penyintas untuk ditemui dan diingat; 2) mendorong dan meningkatkan inklusivitas maupun kontak lintas komunitas; 3) membantu untuk menyatakan penyesalan atas perbuatan masa lalu; 4) memperkuat keadilan, kebenaran, dan identitas bersama; dan 5) sebagai medium untuk rehumanisasi peserta.

Bercerita di kalangan orang dewasa dapat digunakan untuk menghibur dan dapat menjadi alat yang ampuh untuk membangun perdamaian dalam keluarga maupun komunitas yang terpecah. Cerita dapat membantu menyelesaikan konflik dengan mendorong orang untuk memaafkan dan berdamai. Juga dapat bermanfaat dalam menghibur mereka yang berduka atas kematian atau jenis kehilangan lainnya. Mereka yang bercerita dapat memperoleh manfaat dari perasaan bahwa mereka tidak sendirian; bahwa orang lain telah mendengar pengalaman mereka. Ketika difasilitasi dengan terampil, proses bercerita dapat membantu masyarakat mengembangkan rencana untuk 
penyembuhan dan pemulihan (Newell-Jones \& Crowther, 2014). Lebih jauh, menurut studi yang dilakukan oleh Jessica Senehi (2002, Hal. 41-64), proses perdamaian dapat tertolong dengan penggunaan constructive storytelling yang dimaknainya sebagai bercerita secara inklusif yang mendorong kekuatan kolaboratif serta saling pengakuan; menciptakan peluang untuk keterbukaan, dialog, dan wawasan; dan menjadi sarana untuk membawa masalah ke kesadaran; dan menjadi sarana perlawanan nirkekerasan. Bercerita seperti itu membangun pemahaman, kesadaran, dan menyuarakan perlunya perubahan.

Bercerita juga sangat membantu untuk bina damai karena bermanfaat dalam rangka bina karakter, baik semasa konflik untuk mendorong transformasi konflik, maupun di masa damai untuk mencegah berulangnya konflik (Anyeko \& Hoffmann, 2020). Bercerita untuk bina karakter dapat dilakukan dengan menyampaikan kisah-kisah berisi pengalaman nyata atau dengan menggunakan koleksi kisah-kisah fiksi yang hidup dalam masyarakat maupun berupa rekaan si penutur. Apapun isi kisahnya, tujuan dari bercerita untuk bina karakter ini adalah agar pendengar atau pembaca memiliki prinsip, nilai, norma, dan karakter yang memampukan mereka hidup dalam damai serta berupaya mempertahankan perdamaian. Melalui bercerita, pendengar atau pembaca tidak diajari, melainkan diajak untuk menyimak dan memahaminya sendiri, kemudian memetik hikmahnya untuk dibawa pulang ke kehidupan sehari-hari. Pendongeng dan penulis cerita rakyat untuk perdamaian, Margaret Read Macdonald (1994), mengemukakan, "Perdamaian membutuhkan pemeliharaan dan usaha terusmenerus. Sungguh merupakan kerja keras. Sebuah tugas yang tidak berkesudahan." Mengingat pesan dari Margaret ini, maka upaya bercerita dalam rangka bina damai perlu direproduksi terus menerus.

Buku Bercerita untuk Bina Damai: Kumpulan Cerita Rakyat dari Berbagai Penjuru Dunia hadir karena keyakinan akan kekuatan cerita dan bercerita. Studi seperti yang dilakukan oleh Jan Stewart, Marc Kully, Betty Ezati dan Jody Lynn McBrien (2015, Hal. 237-260) telah membuktikan kekuatan cerita dan bercerita. Berbagai cerita yang dikumpulkan dalam buku ini sengaja diterbitkan untuk tujuan non-profit dalam rangka mendokumentasikan cerita rakyat dari berbagai penjuru dunia sehingga dapat dipergunakan oleh publik maupun untuk proses bina damai. Saat ini seni bercerita hampir hilang di beberapa komunitas akibat konflik, akibat dari kehancuran keluarga, atau akibat dari peningkatan teknologi. Penerbitan buku ini dimaksudkan untuk menangkap kembali nilai-nilai dan keterampilan bercerita yang hilang di komunitas kita. Secara khusus, mengikui anjuran Margaret Read Macdonald, buku ini diterbitkan untuk mereproduksi secara berkelanjutan bahan cerita dalam rangka bina karakter damai. Melalui bahan cerita yang dikumpulkan diharapkan tersedia materi pendukung kegiatan pendidikan, pelatihan, dan lokakarya penanganan konflik maupun perdamaian. Berdasarkan pengalaman, di dalam berbagai kegiatan yang disebutkan tadi, cerita sangat menolong untuk menarik perhatian peserta. Bercerita juga menjadi salah satu bentuk kegiatan yang persuasif serta berdampak terhadap peserta.

\section{METODE}

Penyusunan buku tidak lepas dari kesulitan di masa pandemi yang menghantam dunia sejak awal tahun 2020. Pandemi menyebabkan puluhan mahasiswa di Program Studi Ilmu Hubungan Internasional, Universitas Pelita Harapan (Prodi HI UPH) kehilangan kesempatan untuk Kerja Praktik. Berbagai organisasi, lembaga, dan perusahaan yang semula telah menerima para mahasiswa untuk bekerja, atas dasar kesehatan, keselamatan, dan keamanan bersama terpaksa membatalkan keputusan mereka. Atas inisiatif bersama di Program Studi, para mahasiswa dialihkan untuk Kerja Praktik di tiga mata kuliah, salah satunya adalah Resolusi Konflik. Di dalam penyajiaannya sebagai mata kuliah, sebenarnya Resolusi Konflik dimaksudkan untuk memberikan fondasi agar mahasiswa mampu berpartisipasi dalam menemukan resolusi konflik yang timbul di antara negara, masyarakat sipil, dan perusahaan multinasional. Perkuliahannya dalam semester normal mengkombinasikan teori dan praktik dengan 
bobot teori lebih besar dari praktik. Untuk memenuhi harapan dari mata kuliah Kerja Praktik, muatan mata kuliah Resolusi Konflik kemudian mengalami penyesuaian. Bobot penyajian dibalik dengan muatan praktik diperbesar dan muatan teori diperkecil. Mahasiswa diibaratkan sedang bekerja untuk proyek pengabdian kepada masyarakat bernama Youth \& Peace (di bawah asuhan Prodi HI UPH). Untuk memperluas jangkauan dari Program Youth \& Peace diperlukan ketersediaan bahan bacaan sederhana, persuasif, dan inspiratif bagi remaja dan pemuda yang mudah diakses melalui media sosial. Bahan bacaan ini juga diharapkan menjadi materi pengayaan bagi para fasilitator yang terlibat dalam Pelatihan Pendidikan Keterampilan Perdamaian dan Resolusi Konflik. Setelah mendapatkan wawasan resolusi konflik dan perdamaian serta menerima pengarahan di tiga pertemuan awal, para mahasiswa langsung mengerjakan dua proyek, yaitu: 1) mencari dan menuturkan kembali secara tertulis cerita-cerita rakyat dari berbagai penjuru dunia yang bermakna bagi penanganan konflik secara damai; dan 2) melakukan kampanye publik dengan membuat videografi singkat terkait berbagai isu tentang konflik, kekerasan, dan perdamaian.

Berbagai cerita rakyat yang terkumpul merupakan sebagian dari puluhan cerita yang berhasil dituliskan oleh mahasiswa. Cerita rakyat yang ditugaskan untuk mereka tulis memang diharuskan dari luar Indonesia. Bukan bermaksud untuk merendahkan kualitas cerita rakyat di tanah air, tetapi dimaksudkan untuk memperkaya rujukan pengguna cerita rakyat di Indonesia. Tujuan lainnya adalah untuk memperlihatkan bahwa Hubungan Internasional yang baik, di mana berbagai bangsa saling mengenal dan memahami, juga bisa dibangun melalui pengenalan akan kekayaan karya sastra seperti cerita rakyat.

Setiap peserta Kerja Praktik berkontribusi menuliskan kembali satu cerita rakyat. Kriteria cerita rakyat yang harus mereka temukan adalah kisah yang berkembang dan hidup di tengah masyarakat yang telah dituturkan turun-temurun. Kisah dimaksud bisa tentang mitos, legenda, fabel, epos, atau peristiwa sejarah. Cerita rakyat yang akan mereka tuliskan kembali harus mengandung tema resolusi konflik, tindakan nirkekerasan, atau upaya mewujudkan perdamaian. Sangat dianjurkan apabila isi cerita adalah tentang remaja/pemuda atau melibatkan remaja/pemuda sebagai tokoh di dalamnya. Para mahasiswa menemukan cerita dari berbagai sumber, mulai dari kepustakaan klasik hingga materi multimedia dalam format digital yang tersedia banyak di masa sekarang. Sebelum menceritakannya kembali sesuai dengan kriteria yang ditentukan, mereka diminta terlebih dahulu untuk menelaah dengan baik isi cerita dari berbagai sumber yang mereka pakai. Baru kemudian cerita rakyat dituliskan dengan panjang 1.000-2.500 kata.

Dari total 51 cerita yang dihasilkan di kelas Resolusi Konflik, tim penyunting - yang terdiri dari satu dosen senior, satu dosen junior, dan satu alumni yang adalah juga peserta kelas Resolusi Konflik -menemukan 26 cerita yang memenuhi kriteria. Proses penyusunan buku diteruskan dengan proses sunting dan perbaikan naskah agar setiap cerita dapat dibaca dengan alur yang mulus dan konsisten. Proses ini dimulai pada Juni 2021. Setelahnya, proses dilanjutkan dengan pembuatan desain halaman judul (depan dan belakang) buku serta pengaturan tata letak setiap bagian naskah buku, termasuk Kata Pengantar, Daftar Isi, Indeks Karakter, Daftar Kontributor, Isi Buku, serta Profil Penyunting. Pada tahap ini, untuk seterusnya, mahasiswa yang menuliskan cerita disebut sebagai kontributor.

Proses sunting, pembuatan desain halaman judul, dan pengaturan tata letak naskah berlangsung selama hampir dua bulan. Pada 25 Juli 2021, tim penyunting mengirimkan naskah lengkap kepada pihak penerbit buku. Tahapan yang dilakukan bersama penerbit mencakup 1) perbaikan naskah, termasuk sunting bahasa, tata letak, dan pemilihan jenis huruf; 2) pengurusan International Standard Book Number (ISBN) kepada Perpustakaan Nasional Republik Indonesia; 3) pencetakan buku, 4) penerbitan sertifikat para penyunting dan kontributor; 4) serta pembuatan buku versi elektronik (e-book); dan 5) pengiriman buku cetak. Pada 3 September 2021, sebanyak 100 eksemplar buku Bercerita untuk Bina Damai: Kumpulan Cerita Rakyat dari Berbagai Penjuru Dunia tiba di Tangerang, Banten untuk didistribusikan. 


\section{HASIL DAN PEMBAHASAN}

\section{Profil Buku}

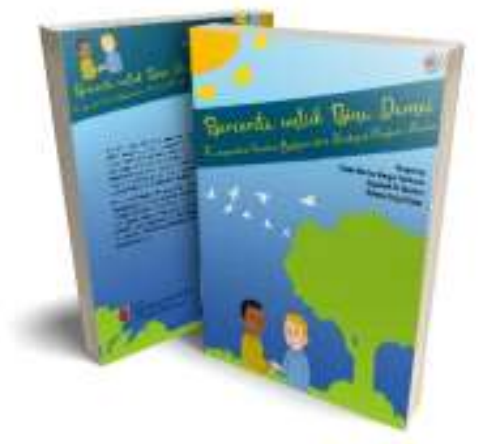

Gambar 1. Tampilan 3D Mock-Up Buku Bercerita untuk Bina Damai: Kumpulan Cerita Rakyat dari Berbagai Penjuru Dunia

Secara ringkas, buku Bercerita untuk Bina Damai: Kumpulan Cerita Rakyat dari Berbagai Penjuru Dunia terdaftar dengan ISBN 978-6236415-30-6 pada Perpustakaan Nasional Republik Indonesia dengan info buku cetak sebagai berikut: 1) Cetakan I pada Agustus 2021;2) setebal xiii + 194 halaman; 3) dicetak dengan kertas bookpaper 72 gram; 4) memiliki dimensi 14,8 x $21 \mathrm{~cm}$ (seukuran kertas A5); dan 5) dengan sampul softcover menggunakan kertas tipe doff berlaminasi. Urutan isi buku antara lain: 1) halaman sampul depan; 2) halaman judul; 3) Kata Pengantar; 4) Daftar Isi; 5) Indeks Karakter; 6) Daftar Kontributor; 7) Pendahuluan; 8) Isi buku yang berupa 26 cerita rakyat; 9) Profil Penyunting; dan 10) halaman sampul belakang.

Seluruh 26 cerita dalam buku berasal dari empat benua, yaitu: Afrika, Asia, Amerika, dan Eropa. Setiap cerita selalu diawali dengan identifikasi karakter (di bawah judul) yang dapat dipelajari dari isi cerita. Tujuannya untuk membantu pembaca mengetahui kontribusi cerita pada pengembangan karakter. Satu cerita tentu saja dapat memuat beberapa jenis karakter. Pembaca diharapkan membingkai ulang cerita apabila hendak memberi penekanan pada karakter tertentu.
Di bawah judul, secara singkat dijelaskan konteks dari cerita, berupa konteks sosial, geografi,

sejarah, atau budaya dari mana cerita berasal. Maksudnya untuk membantu pembaca memahami sekilas latar belakang dari cerita. Di akhir setiap cerita selalu disediakan pesan hikmat untuk menolong pembaca menemukan esensi dari cerita.

Penyajian cerita dalam buku ini dilakukan per kelompok asal benua. Dimulai dari benua di mana Indonesia berada, yaitu Asia. Kemudian berpindah ke Afrika. Eropa menjadi kelompok ketiga. Penyajian cerita berakhir di benua Amerika. Selain daftar isi, untuk memudahkan pencarian cerita yang hendak dirujuk, tersedia juga daftar karakter dari setiap cerita.

Gambar 2. Tampilan Daftar Isi Buku
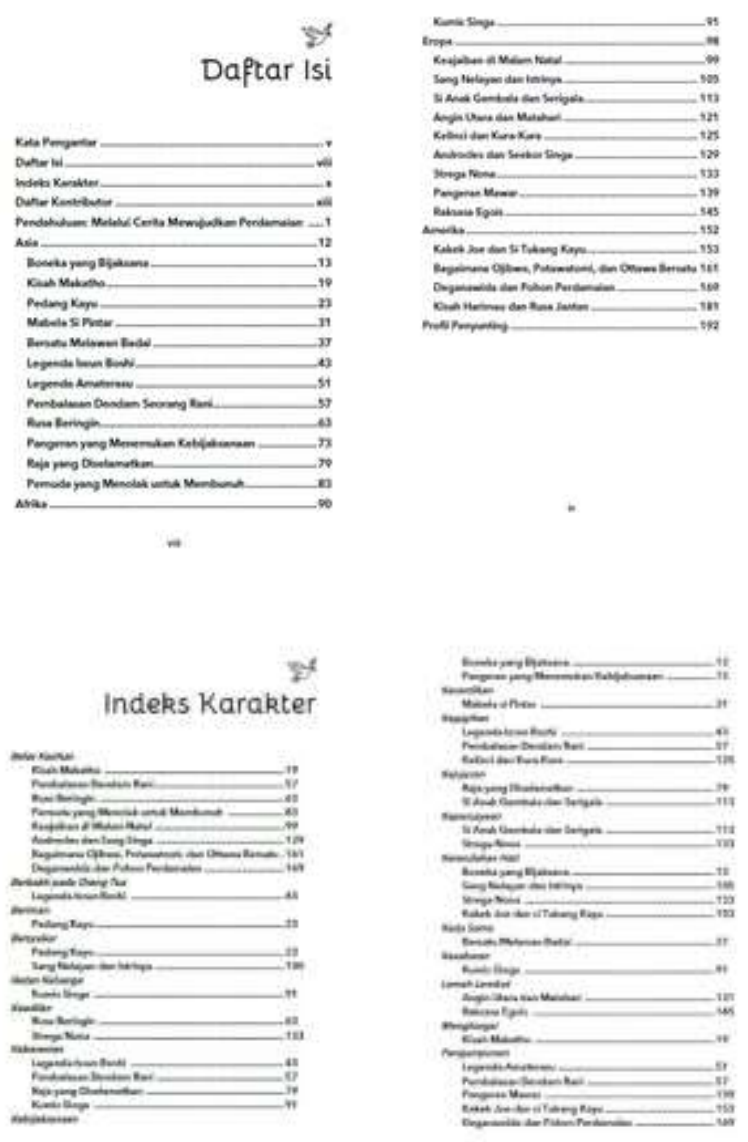

Gambar 3. Tampilan Indeks Karakter pada Buku 


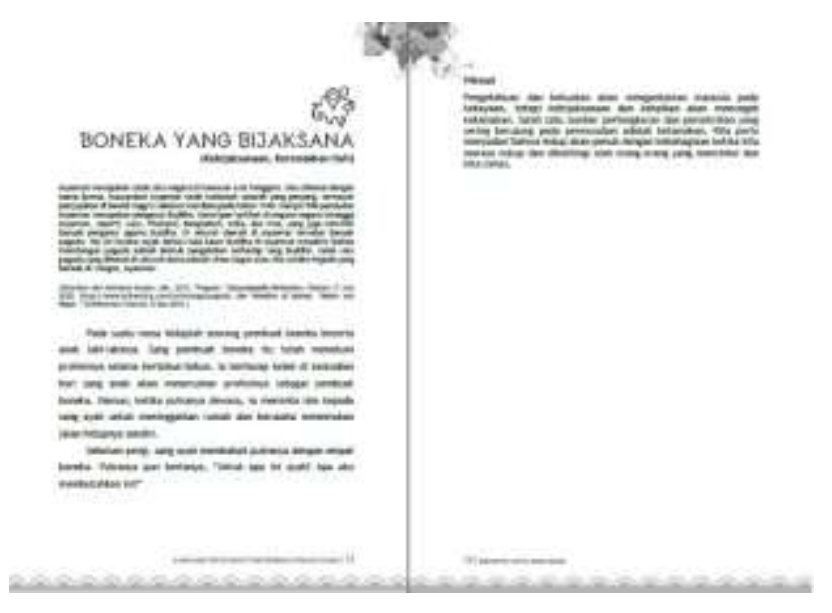

Gambar 4. Contoh Tampilan Awal dan Akhir Cerita

\section{Melalui Cerita Wujudkan Perdamaian}

Buku Bercerita untuk Bina Damai: Kumpulan Cerita Rakyat dari Berbagai Penjuru Dunia merupakan wujud komitmen para penyunting dan kontributor terhadap upaya bina damai yang senantiasa mendesak, tetapi kerap diabaikan. Bina damai dimulai dari diseminasi nilai-nilai perdamaian dengan harapan bibit nilai tersebut akan tumbuh menjadi karakter perdamaian. Orang-orang dengan karakter perdamaian, yang kita sebut sebagai agen perdamaian, kelak akan mengupayakan perdamaian di mana pun mereka berada. Proses konstruksi sosial semacam ini memang akan memakan waktu, tetapi diyakini memiliki daya tahan kuat dan berkelanjutan (Yemenici, 2016).

Secara teoretis, penyusunan buku ini merupakan langkah diseminasi nilai-nilai perdamaian. Ibarat bekerja di ladang, benih tidak disebar hanya pada satu titik, melainkan di banyak titik dibantu oleh mesin. Buku inilah yang menjadi salah satu mesin. Cerita-cerita dalam buku ini diharapkan berkontribusi dalam proses diseminasi nilai-nilai perdamaian sehingga dapat berlangsung lebih cepat dan luas.

Lalu, secara praktis, untuk siapa saja buku ini berguna? Berbagai cerita rakyat, termasuk dalam buku ini, berguna untuk siapa pun dalam rangka membangun budaya perdamaian. Para orang tua dapat menggunakannya untuk anak-anak mereka, khususnya usia pra-remaja dan remaja. Guru-guru di sekolah juga dapat memakainya di dalam kelas untuk berbagai mata pelajaran. Secara khusus, buku ini sangat berguna bagi para pegiat penanganan konflik dan perdamaian.

Cerita-cerita dalam buku ini dapat menjadi rujukan untuk melengkapi materi dalam kegiatan pendidikan, pelatihan, dan lokakarya. Tidak hanya untuk kegiatan storytelling cerita-cerita ini bermanfaat. Berbagai cerita yang ada juga bisa digunakan sebagai kegiatan pembuka (ice breaking) dengan memanfaatkan isi atau tokoh dalam cerita sebagai bagian dari skenario untuk mendorong para peserta berkenalan.

Cerita yang ada juga bisa dimanfaatkan sebagai skenario untuk mengembangkan dinamika kelompok melalui kegiatan bermain peran, visualisasi, dan dramatisasi. Selain itu, cerita-cerita yang ada juga berguna untuk kegiatan penutup dalam sesi-sesi pelatihan atau lokakarya. Melalui cerita yang disampaikan, peserta dapat diajak untuk melakukan refleksi pribadi atau refleksi kelompok. Tentu saja, untuk kebutuhan-kebutuhan spesifik semacam ini, cerita yang hendak dipakai perlu disesuaikan baik panjang maupun cara penyajiannya.

Berangkat dari pemahaman urgensi bina damai, penyusun buku melihat bahwa upaya diseminasi atau penyebaran benih perdamaian perlu dilakukan seluas dan sesegera mungkin. Untuk itu, buku ini tidak dikomersilkan. Bagi yang membutuhkan dalam bentuk cetak, buku dapat diperoleh dengan mengganti biaya cetak yang diberikan penerbit beserta ongkos kirim. Bagi yang membutuhkan versi elektronik, buku ini diberikan secara percuma. Upaya ini dilakukan dengan harapan dapat mendorong minat baca dan percepatan penyebaran pengetahuan perdamaian. Menyadari situasi yang tidak kondusif, metode ini dilihat tepat bagi masyarakat Indonesia yang terhantam pandemi.

Sebagai bentuk penghargaan atas kerja 
kerasnya, setiap kontributor mendapat satu buku cetak yang dikirim ke kediaman masing-masing beserta buku dan sertifikat elektronik. Selain sebagai bentuk apresiasi, tujuan utama lainnya adalah mendorong semangat kolaborasi dosenmahasiswa meskipun sebagian besar kontributor telah menjadi sarjana. Buku ini merupakan luaran (output) dari pendidikan yang ditempuh selama beberapa tahun terakhir.

\section{Keberlanjutan}

Buku Bercerita untuk Bina Damai: Kumpulan Cerita Rakyat dari Berbagai Penjuru Dunia diluncurkan pada 21 September 2021, bertepatan dengan peringatan Hari Perdamaian Internasional (International Day of Peace). Bersamaan dengan peluncuran, digelar pula sebuah webinar yang menggarisbawahi tiga urgensi, yaitu: 1) Storytelling dalam Kajian Konflik dan Perdamaian; 2) Storytelling dalam Kegiatan Bina Damai: Pengalaman Aktivis Perdamaian; dan 3) Storytelling dalam Pendampingan Perempuan dan Anak.

Ketiga urgensi ini merefleksikan efektivitas cerita dan bercerita. Urgensi pertama menekankan pentingnya unsur cerita dan bercerita dalam 1) memory (ingatan); 2) recovery (pemulihan); 3) character building (bina karakter). Urgensi kedua merefleksikan relevansi cerita dan bercerita dalam merespon, menangani, dan transformasi konflik. Urgensi ketiga secara khusus berbicara mengenai bagaimana pemahaman gender yang tepat merupakan unsur yang tidak terpisahkan dari pendidikan perdamaian.

Singkatnya, bina damai merupakan pekerjaan multidisipliner yang membutuhkan keuletan dan ketekunan. Perdamaian tidak diperoleh hanya melalui satu metode dan/atau berfokus pada satu isu. Perdamaian merupakan pekerjaan menyeluruh. Proses bina damai pun membutuhkan pendekatan komprehensif, yaitu top-down dan bottom-up. John Paul Lederach dan Katie Mansfield (2010) mencoba mengindentifikasi jalur-jalur strategis yang dapat ditempuh dalam upaya bina damai. Lederach dan Mansfield kemudian menggambarkannya sebagai berikut:

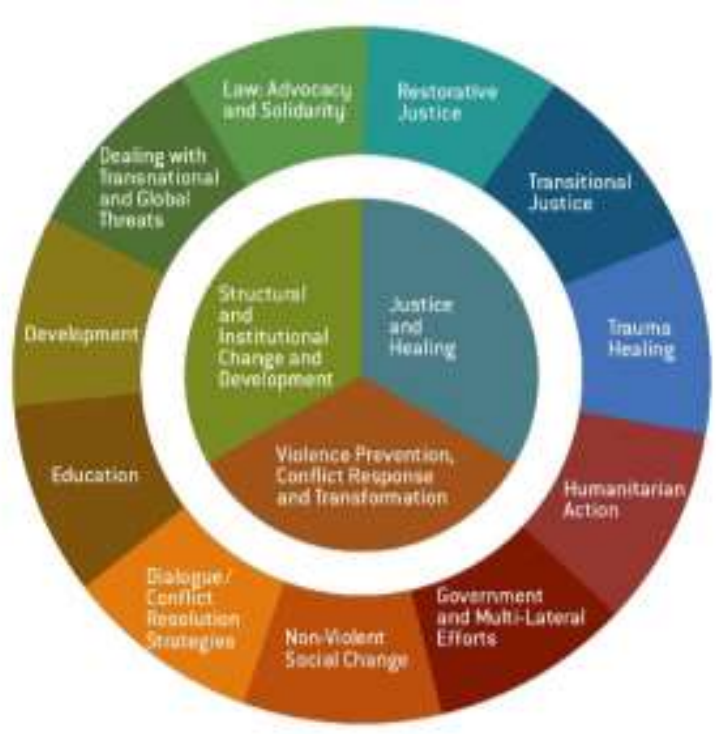

Gambar 5. Strategic Peacebuilding Paths

Peran cerita dan bercerita nampak jelas dalam berbagai jalur yang ditawarkan Lederach dan Mansfield, antara lain dalam 1) pendidikan; 2) dialog/strategi resolusi konflik; 3) pemulihan trauma; 4) mencegah kekerasan; 5) meningkatkan kesadaran aksi kemanusiaan; serta 6) restorative justice.

Menyadari besarnya kekuatan cerita dan bercerita dalam upaya bina damai, baik di Indonesia maupun tataran global, penyusun buku bercita-cita untuk: 1) mengintegrasikan metode cerita dan bercerita dalam proses belajar mengajar di Prodi Hubungan Internasional UPH; 2) mendayagunakan buku dalam rangkaian aktivitas Youth \& Peace Project; 3) menyebarluaskan upaya bina damai melalui cerita dengan membagikan buku versi elektronik dalam berbagai kesempatan.

Selain menuntut keuletan dan ketekunan, bina damai juga menuntut peminatnya untuk bekerja dengan aktif dan kreatif. Peminat Studi Perdamaian harus giat mencari/menciptakan 
kesempatan yang memungkinkan diseminasi nilainilai perdamaian. Pegiat Studi Perdamaian tidak dapat hanya berpangku tangan dan menunggu bola. Inilah yang mendasari keputusan penyusun buku untuk secara cuma-cuma memberikan buku versi elektronik kepada siapa pun yang berminat. Semakin luas paparannya, semakin cepat nilai-nilai perdamaian tertanam.

\section{KESIMPULAN}

Cerita dan bercerita berkontribusi secara nyata dan signifikan dalam upaya bina damai. Metode ini memiliki karakter unik yang tidak dijumpai pada metode bina damai lainnya; cerita dan bercerita memungkinkan seseorang menikmati proses belajar tanpa merasa digurui. Penyusunan buku Bercerita untuk Bina Damai: Kumpulan Cerita Rakyat dari Berbagai Penjuru Dunia didasarkan pada kesadaran bahwa cerita dan bercerita merupakan irisan dari variabel-variabel upaya bina damai; yang setidaknya merupakan pekerjaan multidisipliner serta menuntut keuletan dan ketekunan. Pembacaan cerita-cerita pada buku ini oleh orang tua, guru, aktivis, pegiat Studi Perdamaian, atau elemen lain dalam masyarakat akan mendukung percepatan penyebaran nilai-nilai perdamaian; apalagi jika cerita dibacakan berulang. Pada prinsipnya, pegiat Studi Perdamaian perlu jeli memilah metode bina damai yang praktis, realistis tehadap situasi terkini, dan tentunya bermanfaat. Sebagai sebuah kegiatan pengabdian kepada masyarakat, kehadiran buku ini adalah wujud pendidikan perdamaian.

\section{UCAPAN TERIMA KASIH}

Penyusun buku - penyunting dan para kontributor - berterima kasih kepada Program Studi Hubungan Internasional Universitas Pelita Harapan (Prodi HI UPH) yang membuka kelas Resolusi Konflik pada periode Mei-Juli 2020 dan memungkinkan terkumpulnya naskah-naskah cerita. Apresiasi juga disampaikan kepada Penerbit Salam Rafflesia yang membantu penerbitan dan pencetakan buku.

\section{REFERENSI}

Anyeko, K. \& Hoffmann, T. S. (2020). Storytelling and Peacebuilding: Lessons from Northern Uganda. In J. Mitchell, G. Vincett, T. Hawksley, \& H. Culbertson (Eds.). Peacebuilding and the Arts. Switzerland: Palgrave Macmillan.

Kamara-Umunna, A. G. \& Holland, E. (2011). And Still Peace Did Not Come: A Memoir of Reconciliation. New York: Hyperion.

Lederach, J. P. \& Mansfield, K. (2010). Strategic Peacebuilding Paths. Kroc Institute for International Peace Studies. https://kroc.nd.edu/about-us/what-is-peacestudies/what-is-strategic-peacebuilding/

MacDonald, M. R. (1994). Cerita-cerita Perdamaian: Cerita Rakyat dari Berbagai Penjuru Dunia. Yogyakarta: Kanisius.

Maiangwa, B. \& Byrne, S. (2015). Peacebuilding and Reconciliation through Storytelling in Northern Ireland and the Border Counties of the Republic of Ireland. Storytelling, Self, Society, 11(1), 85-110.

Newell-Jones, K. \& Crowther, R. (2014). Storytelling: A Tool for Promoting Peace and Literacy. London, UK: Feed the Minds.

Senehi, J. (2002). Constructive Storytelling: A Peace Process. Peace and Conflict Studies, 9(2), $41-64$.

Senehi, J. (2000). Constructive Storytelling in Intercommunal Conflicts: Building Community, Building Peace. In Sean Byrne, Cynthia Irvin, Paul Dixon, Brian Polkinghorn, \& Jessica Senehi (Eds.), Reconcilable Differences: Turning Points in Ethnopolitical Conflict. West Hartford, CT: Kumarian.

Stewart, J., Kully, M., Ezati, B., \& McBrien, J. L. (2015). The Importance of Storytelling for 
Peace-building in Post-Conflict States. In L. Finley, J. Connors, \& B. Wien (Eds.). Teaching Peace through Popular Culture. Charlotte, NC: Information Age Publishing, Inc.

Yemenici, A. (2016). Peace Education: Training for an Evolved Consciousness of NonViolence. All Azimuth: A Journal of Foreign Policy and Peace, 5(1), 5-27. 